NASA Technical Memorandum 105637

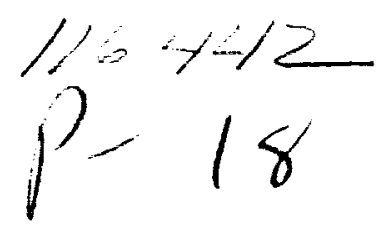

\title{
SP-100 Reactor With Brayton Conversion for Lunar Surface Applications
}

Lee S. Mason, Carlos D. Rodriguez, and Barbara I. McKissock

Lewis Research Center

Cleveland, Ohio

James C. Hanlon

Sverdrup Technology, Inc.

Lewis Research Center Group

Brook Park, Ohio

and

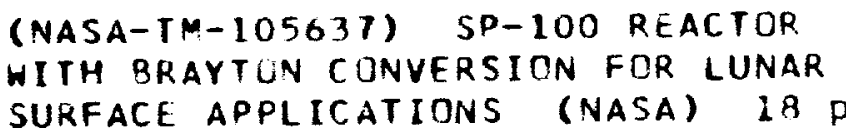
SURFACE APPLICATIONS (NASA) IB
$\mathrm{N} 92-3210 \mathrm{~B}$

Unclas

$63 / 20$

0116442

University of Dayton

Dayton, Ohio

Prepared for the Ninth Symposium on Space Nuclear Power Systems Albuquerque, New Mexico, January 12-16, 1992 


\title{
SP-100 REACTOR WITH BRAYTON CONVERSION FOR LUNAR
}

\section{SURF ACE APPLICATIONS}

\author{
Lee S. Mason, Carlos D. Rodriguez, and Barbara I. McKissock \\ National Aeronautics and Space Administration \\ Lewis Research Center \\ Cleveland, Ohio 44135 \\ James C. Hanlon \\ Sverdrup Technology, Inc. \\ Lewis Research Center Group \\ Brook Park, Ohio 44142 \\ and \\ Brian C. Mansfield \\ University of Dayton \\ Dayton, Ohio 45409
}

\section{SUMMARY}

This study examines the potential for integrating Brayton-cycle power conversion with the SP-100 reactor for lunar surface power system applications. Two designs were characterized and modeled. The first design integrates a 100-kWe SP-100 Brayton power system with a lunar lander. This system is intended to meet early lunar mission power needs while minimizing on-site installation requirements. Man-rated radiation protection is provided by an integral multilayer, cylindrical lithium hydride/tungsten $(\mathrm{LiH} / \mathrm{W})$ shield encircling the reactor vessel. Design emphasis is on ease of deployment, safety, and reliability while utilizing relatively near-term technology. The second design combines Brayton conversion with the $\mathrm{SP}-100$ reactor in an erectable 550-kWe powerplant concept intended to satisfy later-phase lunar base power requirements. This system capitalizes on experience gained from operation of the initial $100-\mathrm{kWe}$ module and incorporates some technology improvements. For this system the reactor is emplaced in a lunar regolith excavation to provide man-rated shielding, and the Brayton engines and radiators are mounted on the lunar surface and extend radially from the central reactor. Design emphasis is on performance, safety, long life, and operational flexibility.

\section{INTRODUCTION}

Recent studies examining approaches for lunar base missions have suggested a need for nuclear reactor power systems (Synthesis Group Report, 1991). Most mission development strategies suggest a phased approach for meeting mission objectives. Power requirements for permanent-occupancy lunar surface missions range from tens of kilowatts for the early emplacement phases to hundreds of kilowatts for the later operational phases. Nuclear reactor power systems provide a low-mass, long-life option for meeting these requirements.

One strategy for satisfying lunar base power requirements is through a centralized utility. Power could be generated by multiple systems and provided to a central user-common switching station. From the switching station electric power would be distributed to the various users as shown in figure 1. The stated power requirements are commensurate with results from NASA's 
90-day study of the Moon and Mars. Within the power generation area an initial nuclear reactor system could be emplaced that would have the capacity to meet near-term power requirements associated with the emplacement phase. Principal power users for this phase of the mission might include initial crew habitat modules, science platforms, rover recharging facilities, and in-situ resource utilization (ISRU) demonstrations. A photovoltaic and regenerative fuel cell (PV/RFC) system might also be utilized to provide redundant power to the habitat life support systems. If the lunar base grows and power requirements increase to accommodate laboratory modules, constructible habitats, liquid oxygen plants, launch and landing servicing facilities, and expanded science, a subsequent larger nuclear reactor system could be delivered to complement and eventually replace the original system.

\section{GROUNDRULES AND DESIGN GUIDELINES}

This study characterizes two different SP-100 Brayton systems. The first system is sized for $100 \mathrm{kWe}$ and is designed to be self-deployable. It was assumed that this system would be one of the first elements delivered to the lunar surface and therefore could rely on no equipment or manpower for its installation. It was concluded that a design in which the power system is integrated with a lunar lander would best satisfy this requirement. This concept had been explored as an option for an easily deployable, self-contained power system for a periodically tended lunar observatory mission (Hickman and Bloomfield, 1989). An integrated lithium hydride/tungsten ( $\mathrm{LiH} / \mathrm{W}$ ) enclosure shield is included for crew radiation protection. Although it was assumed that no infrastructure would be available for the deployment of the system, it was also assumed that crew members would be available to make the final electrical transmission line connections and to initiate system startup. A 10-year-equivalent, full-power system lifetimewas assumed. Operation of the reactor at less than full thermal power could potentially extend the system's service life.

The second system is sized for $550 \mathrm{kWe}$. This system is assumed to be delivered to the Moon when power requirements have increased to account for a full operational liquid oxygen production facility. Because this system would be delivered once the base is established, it was assumed that a crew would be available for its installation. The basic concept consists of a single $\mathrm{SP}-100$ reactor located in a cylindrical hole with surface-mounted Brayton engines and radiators. Man-rated radiation protection is provided through the emplacement of the reactor in the excavation. Despite the crew availability this powerplant is designed for quick and easy assembly. It would be delivered to the site with all interface piping preconnected and would only require the placement of the reactor in the excavation, installation of the radiator panels, and final electrical transmission line connections. As in the 100-kWe case a 10-year-equivalent, full-power system life was assumed.

\section{Reactor and Primary Heat-Transport System}

In both cases SP-100 reactor technology is assumed. SP-100 is a joint Department of Energy (DOE), NASA, Department of Defense (DOD) program to develop a space reactor power system. The reactor subsystem consists of uranium nitride (UN) fuel pins, reflector controls, safety rods, pressure vessel, auxiliary coolant loop, and instrumentation and controls. For this study the thermal power of the reactor was allowed to vary with the electric power output and the power conversion efficiency. In addition to the man-rated shielding the $100-\mathrm{kWe}$ and $550-\mathrm{kWe}$ systems also include an instrument radiation shield directly above the reactor for the 
reflector control actuators, the safety rod drives, and the reactor instrumentation. The $100-\mathrm{kWe}$ system employs an additional instrument shield below the reactor to reduce ground scattering. Because $\mathrm{SP}-100$ is a liquid-lithium-cooled reactor, a liquid-metal-to-gas heat exchanger is required for the Brayton. Both systems utilize a segmented heat exchanger with redundant inlet and outlet manifolds for the reactor and one for each of the Brayton engines. Included in the primary heat transport system is the heat exchanger, the inlet and outlet piping, and the electromagnetic pumps.

\section{Man-Rated Shielding}

The radiation shielding strategies for both the $100-\mathrm{kWe}$ and $550-\mathrm{kWe}$ systems are shown in figure 2. The 100-kWe system utilizes an integral man-rated shield to protect the lunar base crew members. The shield circumferentially surrounds the reactor core and consists of alternating layers of tungsten and lithium hydride. The circumferential shield, although primarily intended to attenuate radiation directed toward the crew habitat, permits crew excursions and base expansion in any direction around the system. The dose constraints for sizing this shield were conservatively selected to be less than 5 rem in 6 months at a separation distance of $1000 \mathrm{~m}$. This dose rate would vary with the inverse square of the separation distance. The 5-rem dose limit is consistent with the Occupational Safety and Health Administration (OSHA) annual dose limit for terrestrial nuclear powerplant workers, and 6 months has been suggested as a typical tour of duty for a lunar base crew member. This limit is far below the 50-rem annual limit for astronauts proposed in National Council on Radiation Protection and Measurements Report Number 98 (1989). The conversative dose constraint was chosen to minimize the reactor's contribution to the cumulative radiation environment (including natural and other man-made sources) imposed on the crew.

The 550-kWe system relies on an excavated cylindrical hole to provide man-rated shielding. The surrounding lunar regolith acts to attenuate radiation in all directions around the reactor. Figure 3 shows that radiation from a 2.5-MWt SP-100 type of reactor enclosed in a 3.5-m-deep, 1.5-m-diameter hole can be attenuated to less than 5 rem in 6 months at a distance of $7 \mathrm{~m}$ from the reactor centerline. This shielding approach eliminates the need for the massive circumferential shield used in the 100-kWe system designs. The excavation shield also permits relatively close, human proximity operations and the potential for repair of surface-mounted power system equipment. For this design the same 3.5-m-deep, $1.5-\mathrm{m}$-diameter excavation is assumed. In addition, the reactor assembly is completely enclosed in a multimaterial bulkhead consisting of a 10-cm-thick $\mathrm{LiH}$ upper scatter shield and a $2.5-\mathrm{cm}$-thick boron aluminum hole liner. The bulkhead is included to reduce the neutron scatter current out the top and through the sides of the excavation while enabling easier handling, delivery, and emplacement of the reactor assembly. The thermal conditions within the bulkhead result in the need for the dedicated cavity cooling system. This is accomplished through coolant tanks surrounding the bulkhead that feed surface-mounted radiators.

\section{Brayton-Cycle Power Conversion}

Because the 100-kWe system would likely be one of the earliest delivered lunar base elements, it was decided to utilize a nonrefractory Brayton system and limit the turbine inlet temperature to $1144 \mathrm{~K}$ as a "baseline." Brayton rotating units operating at turbine inlet 
temperatures in this range underwent successful testing during the late 1960's and early 1970's. Because the mission start date is undefined, a high-temperature system was also evaluated that fully utilized the $1350 \mathrm{~K}$ outlet temperature of the baseline SP-100 reactor. This "advanced" design point has a $1300 \mathrm{~K}$ turbine inlet temperature. The $550-\mathrm{kWe}$ system would be delivered somewhat later in the development of the lunar base. For this reason it was assumed that a refractory Brayton system could be available. Therefore, the turbine inlet temperature was based on the outlet temperature of the SP-100 reactor. The higher temperature can further be justified by considering the $100-\mathrm{kWe}, 1144 \mathrm{~K}$ system as an evolutionary step toward the design and implementation of the $550-\mathrm{kWe}, 1300 \mathrm{~K}$ system. The cycle state points have been chosen in both cases to represent a compromise between the minimum-mass design point and the minimum-radiator-area design point. Table I lists the parameters that were varied in determining the final design point.

For this study the Brayton engines were assumed to operate in a parallel mode with at least one redundant engine. Parallel operation assumes that all engines operate initially at partial power. If an engine failure occurs, the power of the remaining engines can be increased to account for the loss. The alternative would be to operate the required engines at full power and maintain the redundant engines in cold standby. The advantage of the parallel mode is that there are no cold-engine startup problems and no complicated switching schemes in the primary and secondary heat transport loops. The disadvantage of parallel operation is that the engines must be able to operate over a wide range of operating characteristics (i.e., off design). However, this disadvantage is not as extreme in the case of Brayton engines, which are able to tolerate off-design conditions with minimal performance penalty.

\section{Heat Rejection}

The heat rejection system for the $100-\mathrm{kWe}$ system is designed to fit within the lander system and be self-deployable. Previous designs for systems of this nature have shown a conical, deployable radiator that extends above the lander and is located within the instrument shield half-angle to eliminate back scattering (Hickman and Bloomfield, 1989). This is probably not the best approach because the radiator panels view downward toward the lunar surface rather than outward toward the colder sink of deep space. Analyses for the radiator design focused on configurations that minimize radiator area through favorable view factor geometries. Waste heat from all the Brayton engines in transferred to a single, gas-to-liquid-sodium-potassium (NaK) heat exchanger. This system uses a shared radiator system in which the NaK is pumped through an armored manifold to a number of heat-pipe radiator panels connected in series. Because this manifold is vulnerable to single-point failures, an independent standby loop was included.

For the 550-kWe each Brayton engine has its own dedicated radiator panel that is capable of rejecting the waste heat associated with peak engine power. During nominal operation, only a percentage of the radiator is used to reject the required heat load. This design approach allows failure of a radiator panel (or Brayton engine) without compromising full-power output. Each Brayton engine has a waste heat, gas-to-liquid-metal heat exchanger and a secondary pumpedloop manifold with $\mathrm{NaK}$ as the working fluid. Heat-pipe heat rejection was selected for both the $100-\mathrm{kWe}$ and $550-\mathrm{kWe}$ systems because of the inherent reliability associated with the large number of heat pipes in any particular radiator segment. In both cases mass estimates were determined from detailed analyses rather than from an assumed mass per unit radiator area. 
Brayton-cycle conversion intrinsically rejects waste heat over a wide temperature range. For this reason multiple heat-pipe fluids may be required depending on cycle state-point conditions. Another approach that may better accommodate the wide temperature range is a pumped-loop radiator system. However, pumped-loop systems are more vulnerable to singlepoint failures. This vulnerability can be reduced by a combination of armoring, redundancy, and loop segmenting at the expense of additional mass. Further study is necessary to fully examine the advantages and disadvantages of pumped-loop heat rejection for this application.

\section{Power Conditioning, Control, and Distribution}

The power-conditioning, control, and distribution (PCC\&D) approach for both the 100-kWe and 550-kWe systems is presented in figure 4. For both systems an ac-ac converter is included to convert the alternator output to a suitable voltage for long-distance transmission. Studies have shown that high-voltage transmission is a favorable method for reducing the mass of the cabling for lunar base missions with multiple, distributed users (Gordon, 1990). Longdistance cabling might also be desirable when nuclear systems are utilized so as to provide safe separation distances between crew and powerplant. The ac-ac converter consists of transformers, ancillary control, and circuit protection in a thermally conductive enclosure with heat-pipe radiator cooling. The output of the converter is assumed to be $5000 \mathrm{~V} \mathrm{rms}$, which is transmitted to a switching station located $1 \mathrm{~km}$ from the powerplant. The transmission lines to and from the ac-ac converter are assumed to be vacuum-insulated, three-wire, aluminum ac conductors. The Brayton alternators for the 100-kWe system would utilize a shared power-conditioning and control system with the number of independent channels and output transmission lines matching the total number of rotating units. The $550-\mathrm{kWe}$ system would employ an engine-dedicated power-conditioning and control system with redundant channels for each converter. The output of the converters would then be combined into a switchgear box with a single, redundant transmission line output.

\section{0-kWe SYSTEM DESIGN}

The 100-kWe design has the reactor, the power conversion units, and the heat exchangers enclosed in a cylindrical protective shell that is supported by the lander structure. The deployed system is presented in figure 5. A cross section of the internal components of that shell is shown in figure 6 with the cylindrical man-rated shield cut away to display the reactor core. The range of temperatures for heat rejection required that a combination of mercury and water heat pipes be used for both designs. A schematic of the radiator design is presented in figure 7 . In an attempt to maximize the radiator's view of deep space the final radiator design consists of four horizontal panels that extend radially from the common waste heat exchanger. Each of the panels is $4 \mathrm{~m}$ wide. The heat transport duct lengths were found to be $16 \mathrm{~m}$ for the baseline case and $11 \mathrm{~m}$ for the advanced case. In order to minimize the effect of incident sunlight, optical solar reflectors are employed on the radiator that render a surface emissivity of 0.80 and a solar absorptivity of $\mathbf{0 . 0 8}$. Radiation scattering is avoided because the deployed radiator panels are within the zone protected by the circumferential shield. The system would be delivered on the lander with the radiator panels stowed upward as shown in figure 8 and deployed by batterypowered motors upon landing.

Figure 9 shows the effect of the number of engines on system reliability and mass. Component reliabilities were assumed to be 0.99 for the reactor, 0.95 for each Brayton engine, 0.99 
for the radiator, and 0.98 for the PCC\&D. The inherent approximation resulting from applying reliability equations to first-of-a-kind systems such as the ones described in this report is acknowledged. In the context of this study the particular values determined for system reliability were of minimal value. Rather, it was the trend that influenced the selection of the number of engines on the basis of the point where increasing system mass was of little benefit in improving system reliability. Curves are provided for cases of both one and two spare engines. System reliability is highest for designs employing a minimal number of engines. These designs have a greater fraction of engine redundancy (ratio of spare engines to total engines). System mass is also highest for these designs because such a large portion of the power conversion capacity goes unused under normal circumstances. Lower system mass is achieved as the number of engines is increased and the fraction of engine redundancy is reduced. However, the mass savings become negligible for large numbers of engines. As exhibited in the baseline case, this trend eventually yields a minimum-mass design after which the addition of more engines acts as a liability to both mass and reliability. In an attempt to satisfy both high system reliability and low system mass while keeping the number of engines to a minimum in order to simplify interface piping, a final design point of three engines including one spare was selected for both the baseline and advanced $100-\mathrm{kWe}$ cases. The comparison between one- and tworedundant-engine systems shows that for the single-spare designs, low mass and high reliability can be achieved with fewer total engines.

Design-point performance and mass for the two $100-\mathrm{kWe}$ cases is presented in table II. The engine design power coincides with the case of all engines operating in parallel to produce the $100-\mathrm{kWe}$ net power output. In the event of a failure the two remaining engines would operate off deign at approximately $50 \mathrm{kWe}$ per unit to provide full power output. Figure 10 shows the tradeoff of system mass and radiator area. The right-most data point of each curve represents the global minimum-mass design. The data points to the left are cases in which the mass has been minimized while constraining radiator area to be less than the global mass minimum. The design point was chosen to reflect a compromise between minimum mass and minimum radiator area. As indicated in the performance summary, the man-rated shield is the dominant mass item of the two systems, making up nearly 50 percent of the overall mass. A modest mass savings of $855 \mathrm{~kg}$ is realized for the higher turbine inlet temperature design conditions.

\section{0-kWe SYSTEM DESIGN}

The 550-kWe system is depicted in figure 11, showing a closeup of the reactor and the power conversion system. The radiator panels are arranged in a vertical orientation and extend radially from the engine-dedicated waste heat exchangers. As in the 100-kWe cases, mercury and water heat pipes are utilized for heat rejection. The radiator design schematic for this system is shown in figure 12. The panels are tapered with three sections of varying height for the high-temperature mercury, low-temperature mercury, and water heat pipes. The total duct length of a radiator panel was determined to be $35 \mathrm{~m}$. These panels would be delivered to the lunar surface in sections and assembled at the site. An insulating lunar surface blanket was employed to improve the spectral characteristics of the lunar soil and to reduce the effective sink temperature to $225 \mathrm{~K}$ (Bien and Guentert, 1969). In order to minimize the probability of secondary-loop meteoroid puncture, the radiator piping and heat-pipe evaporator sections would be buried in the lunar regolith.

The effect of the number of engines on mass and reliability for the 550-kWe system is provided in figure 13. Component reliabilities were identical to those assumed for the 100-kWe 
cases. The effect of engine redundancy on system mass is more pronounced in this design because each engine has a dedicated radiator and PCC\&D subsystem. For this application a final design point of four engines including one spare was chosen to reflect the best compromise of system reliability and mass. As in the $100-\mathrm{kWe}$ cases there appears to be no advantage for multispare designs.

Systems performance and mass are presented in table III. The 196.2-kWe engine design is based on the situation where one engine has failed and the remaining three must produce the rated $550-\mathrm{kWe}$ system output. This approach was used in sizing the higher power system so that worst-case conditions could be imposed on the heat rejection subsystem. Initially, the engines would be operated off design at a lesser power level to achieve the rated system power. The tradeoff of system mass and radiator area is presented in figure 14 . The global minimummass design point is the furthest right of the data points with area-constrained minimum-mass design points toward the left. By accepting a 2-percent mass penalty from the global minimum mass, almost 10-percent radiator area savings is realized for the final design point. The systemspecific mass represents a significant improvement over the two $100-\mathrm{kWe}$ systems. This can be attributed to component economies of scale resulting from the higher power output and the utilization of in-situ materials to provide man-rated shielding.

\section{CONCLUSIONS}

Both of the designs presented in this paper offer distinct advantages for lunar surface power generation. The $100-\mathrm{kWe}$ system is a safe, reliable design that requires minimal manpower for installation and uses relatively near-term technology. It is ideal for initial lunar base power requirements. The $550-\mathrm{kWe}$ system is applicable when power requirements have increased to accommodate extensive in-situ resource utilization. Its design is consistent with the needs of an evolved lunar base: performance, safety, long life, and operational flexibility. The potential advantages of the centralized power utility approach suggested in this report include redundancy, user growth accommodation, reduced development cost, and simplified logistics. For nuclear reactor systems an additional advantage of a central utility is that all of the power systems can be collocated in a single remote area for safety.

\section{REFERENCES}

Bien, D.D.; and Guentert, D.G., 1969, A Method for Reducing the Equivalent Sink Temperature of a Vertically Oriented Radiator on the Lunar Surface. NASA TM X-1729.

Executive Office of the President, Synthesis Group, 1991, America at the Threshold-America's Space Exploration Initiative. Government Printing Office, Washington D.C. 20402.

Gordon, L.B., 1990, Electrical Transmission on the Lunar Surface. NASA Contract NAG3-1055, Space Power Institute, Auburn University, AL.

Hickman, J.M.; and Bloomfield, H.S., 1989, Comparison of Solar Photovoltaic and Nuclear Reactor Power Systems for a Human-Tended Lunar Observatory. NASA TM-102015.

National Council on Radiation Protection and Measurements, 1989, Guidance on Radiation Received in Space Activities, NCRP Report No. 98. 
TABLE I.-PARAMETERS VARIED IN DETERMINING DESIGN-POINT SELECTION

\begin{tabular}{|c|c|c|c|}
\hline Subsystem & $\begin{array}{l}\text { Parameter } \\
\text { varied }\end{array}$ & Subsystem & $\begin{array}{c}\text { Parameter } \\
\text { varied }\end{array}$ \\
\hline Reactor & $\begin{array}{l}\text { Core L/D } \\
\text { Fuel pin diameter } \\
\text { Fuel smear density } \\
\text { Gamma shield thicknesa } \\
\text { Heat source heat exchanger: } \\
\text { Effectiveness } \\
\Delta \mathrm{P} / \mathrm{P} \\
\text { Heat capacity ratio }\end{array}$ & $\begin{array}{l}\text { Power } \\
\text { conversion }\end{array}$ & $\begin{array}{l}\text { Number of engines } \\
\text { Compressor: } \\
\text { Inlet temperature } \\
\text { Pressure ratio } \\
\text { Bleed flow } \\
\text { Inlet pressure } \\
\text { Recuperator: } \\
\text { Effectiveness } \\
\Delta P / P \\
\text { Duct diameters } \\
\text { Rotating speed } \\
\text { He-Xe molecular weight }\end{array}$ \\
\hline Heat rejection & $\begin{array}{l}\text { Heat transport duct: } \\
\Delta P / P \\
\text { Duct length } \\
\text { Fin width } \\
\text { Materials selection } \\
\text { Watte heat exchanger: } \\
\text { Effectiveness } \\
\Delta \mathrm{P} / \mathrm{P} \\
\text { Heat pipe redundancy } \\
\text { Heat pipe length }(550 \mathrm{~kW} \text { system } \\
\text { only) }\end{array}$ & PCC\&D & $\begin{array}{l}\text { Number of channele } \\
\text { Transformer efficiency } \\
\text { Conductor: } \\
\text { Temperature } \\
\text { Diameter } \\
\text { Efficiency }\end{array}$ \\
\hline
\end{tabular}

TABLE II.-100-kWe PERFORMANCE SUMMARY

\begin{tabular}{|c|c|c|}
\hline Parameter & Baseline & Advanced \\
\hline Turbine inlet temperature, $\mathbf{K}$ & 1144 & 1300 \\
\hline Compressor inlet temperature, $K$ & 379 & 414 \\
\hline Compressor inlet pressure, $\mathrm{kPa}$ & 137 & 157 \\
\hline Compressor pressure ratio & 1.86 & 1.81 \\
\hline Recuperator effectiveness & 0.939 & 0.918 \\
\hline Helium-xenon molecular weight & 22.8 & 25.8 \\
\hline Rotating speed, rpm & 58097 & 57950 \\
\hline Engine design power, $\mathrm{kWe}$ & 35.6 & 35.6 \\
\hline Engine efficiency & 0.279 & 0.273 \\
\hline Net system efficiency & 0.261 & 0.256 \\
\hline Reactor thermal power, $\mathrm{kWt}$ & 383 & 391 \\
\hline Total main radiator area, $\mathrm{m}^{2}$ & 260 & 180 \\
\hline Reactor subsystem weight, $\mathrm{kg}$ & 1136 & 1143 \\
\hline Man-rated shield subsystem weight, $\mathrm{kg}$ & 4193 & 4251 \\
\hline Brayton subsystem weight, $\mathrm{kg}$ & 1463 & 1082 \\
\hline Heat-rejection subsystem weight, kg & 2219 & 1680 \\
\hline PCC\&D subsystem weight, kg & 495 & 495 \\
\hline Total mass, $\mathrm{kg}$ & 9506 & 8651 \\
\hline System specific mass, $\mathrm{kg} / \mathrm{kWe}$ & 95 & 87 \\
\hline
\end{tabular}


TABLE III.-550-kWe PERFORMANCE SUMMARY

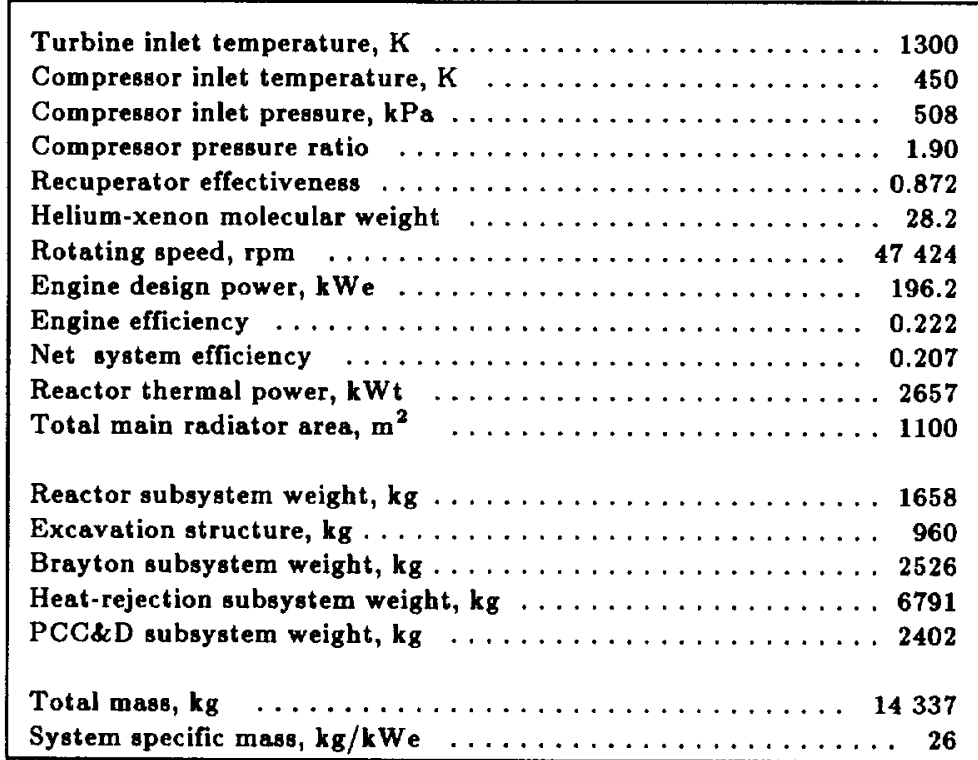

Emplacement phase elements

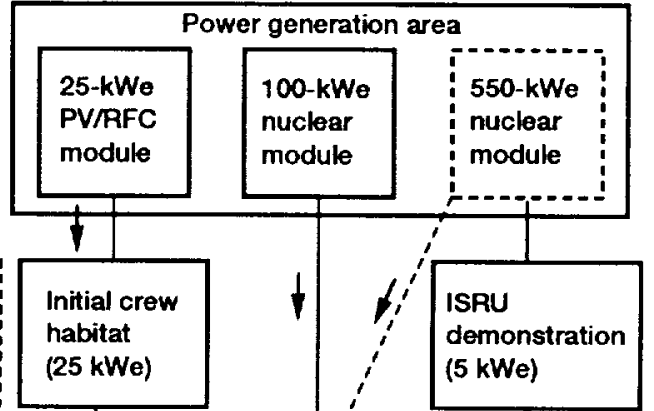
Liquid oxygen Liquid oxygen pilot plant íproduction (45 kWe) ; plant (200 kWe)

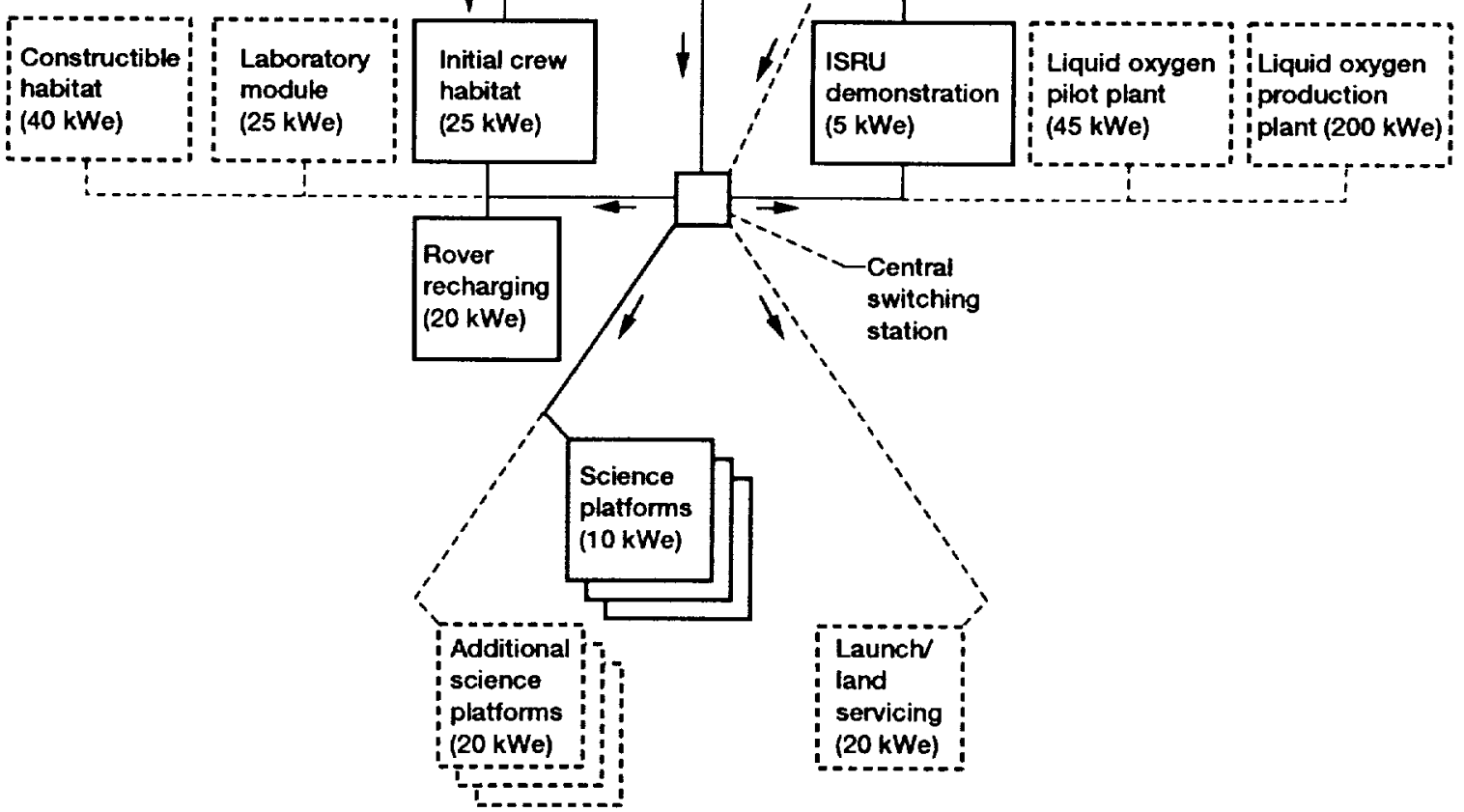

Figure 1.-Representative base layout and power distribution network. 


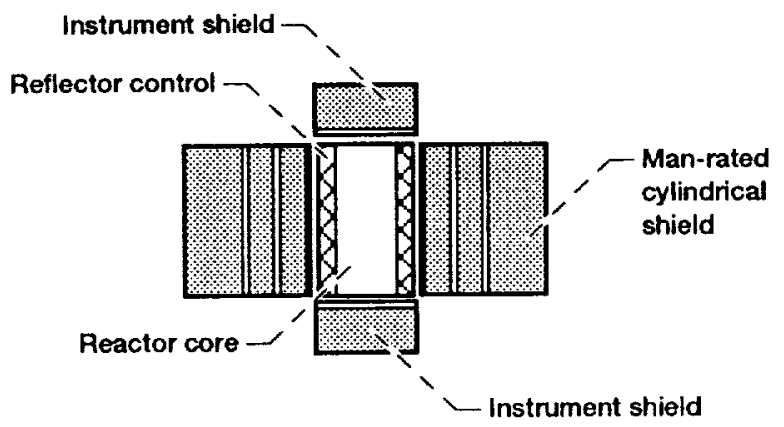

(a) 100-kWe system.

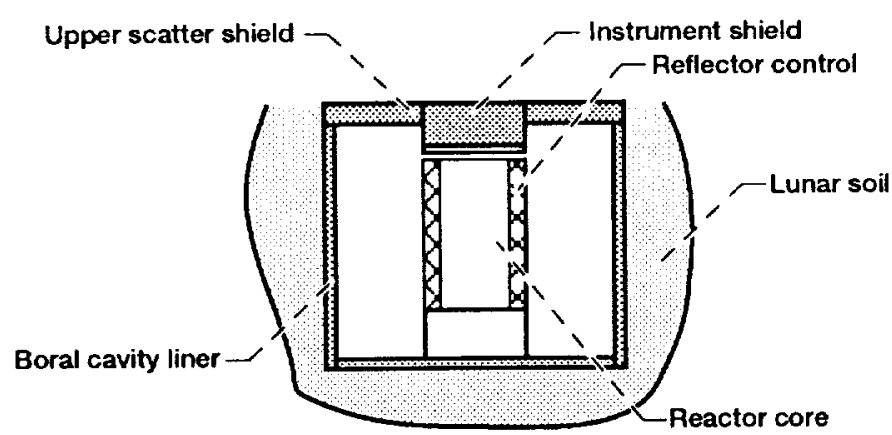

(b) 550-kWe system.

Figure 2.-Reactor radiation shielding strategies to achieve man rating.

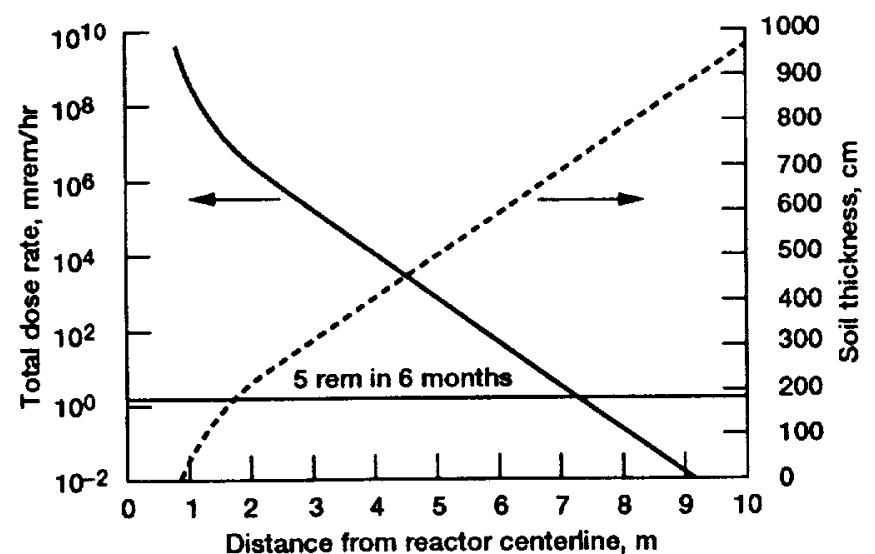

Figure 3.-Radiation attenuation of $\mathrm{SP}-100$ reactor located in lunar excavation. 


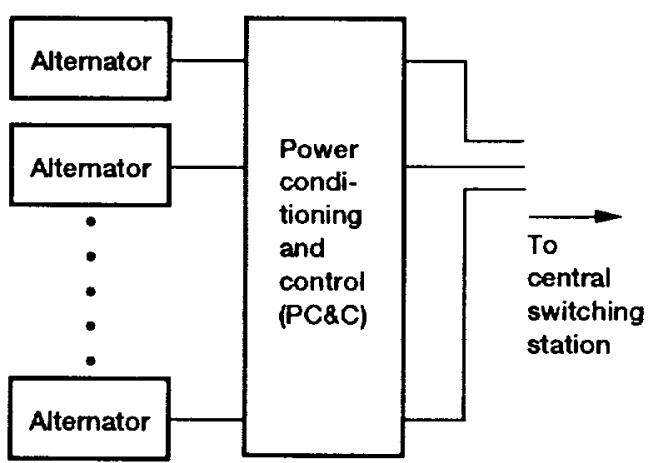

(a) 100-kWe system.

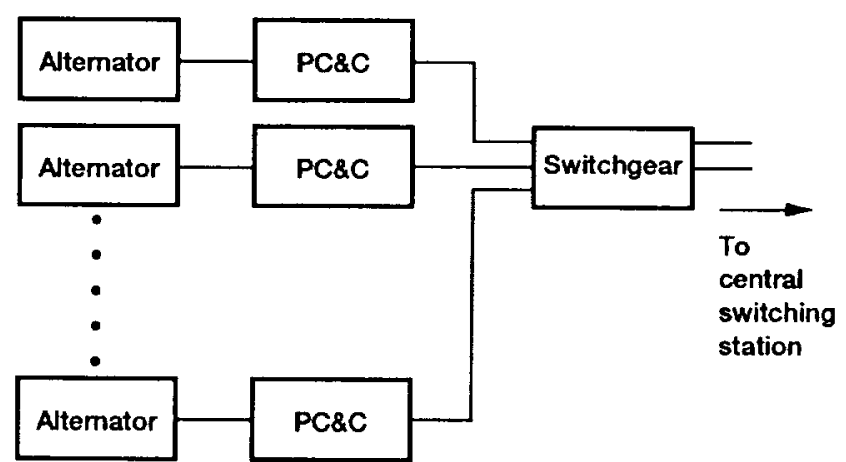

(b) 550-kWe system.

Figure 4.-Power-conditioning, control, and distribution approaches.

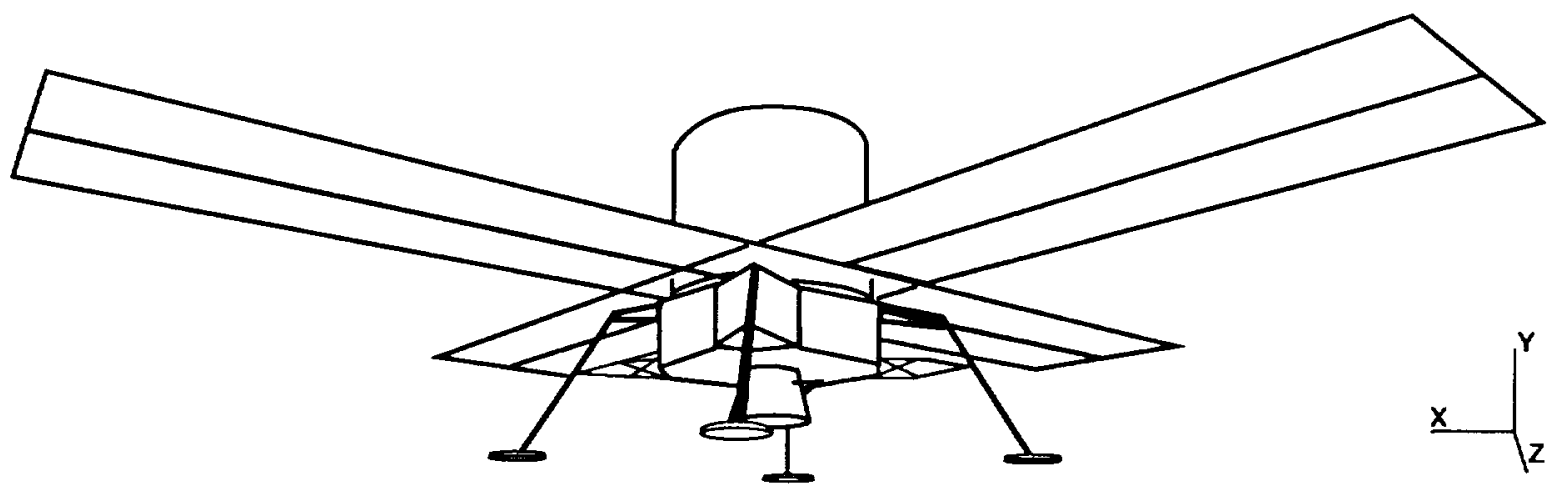

Figure 5.-100-kWe system in deployed configuration. 


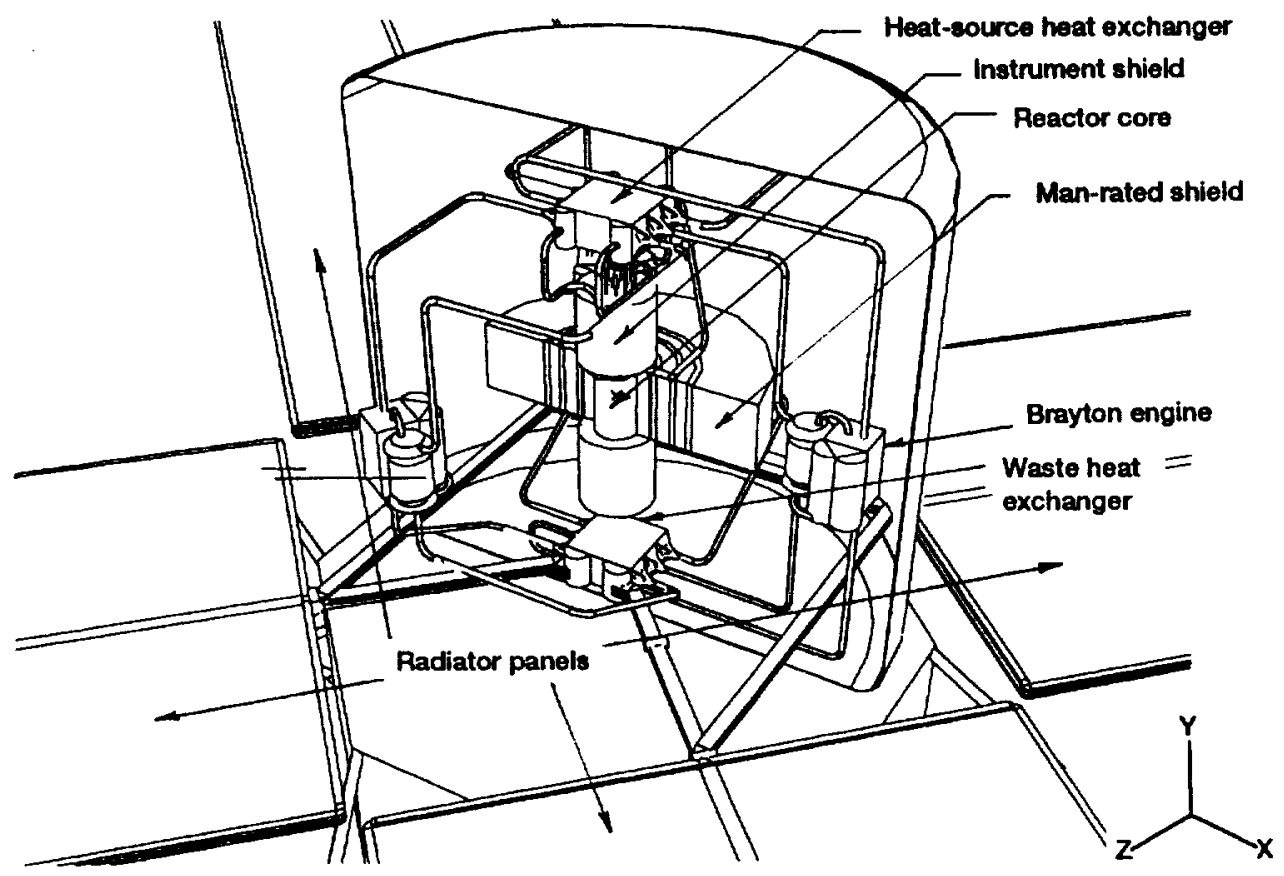

Figure 6. -100-kWe system design layout. 


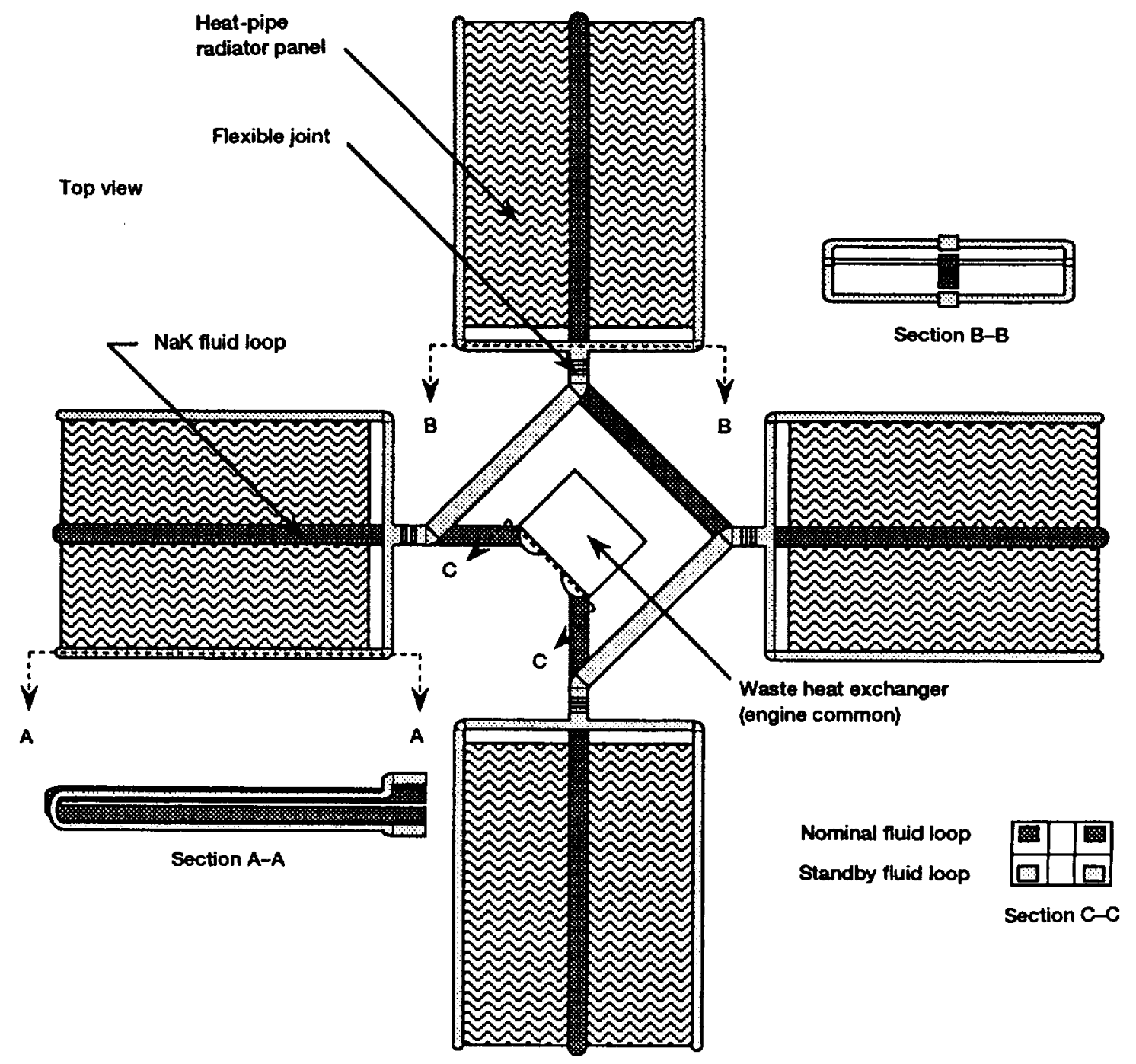

Figure 7.-100-kWe system radiator design. 


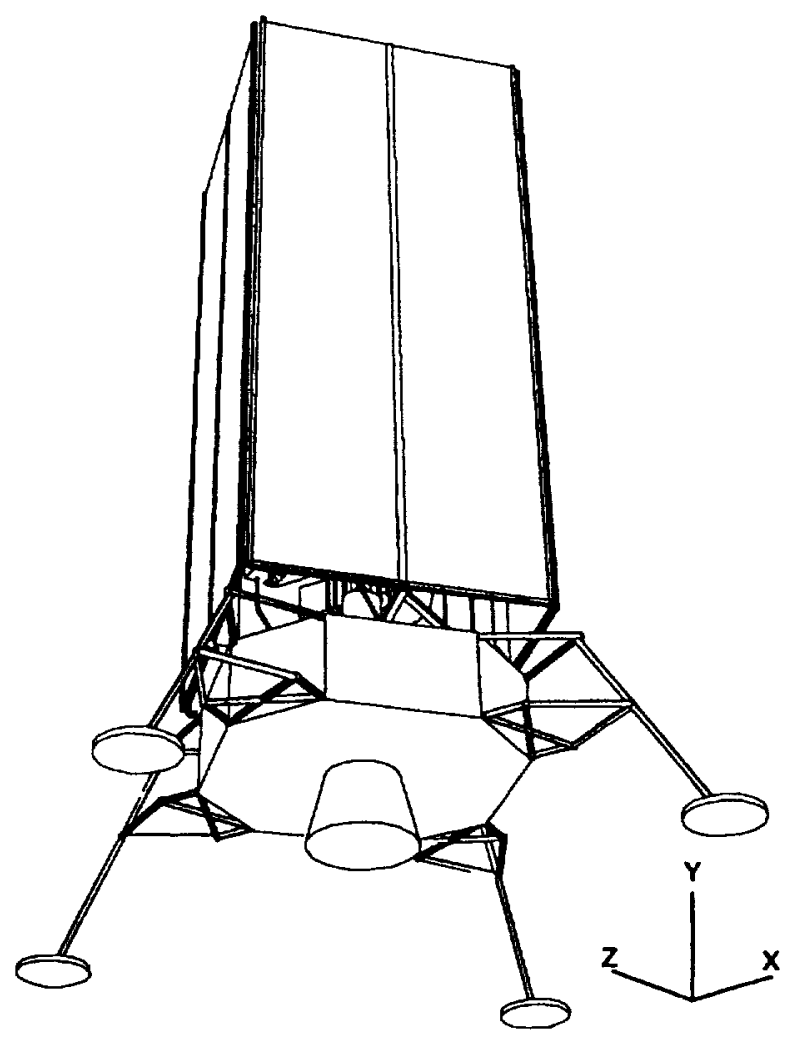

Figure 8. Stowed configuration of 100-kWe system landing.

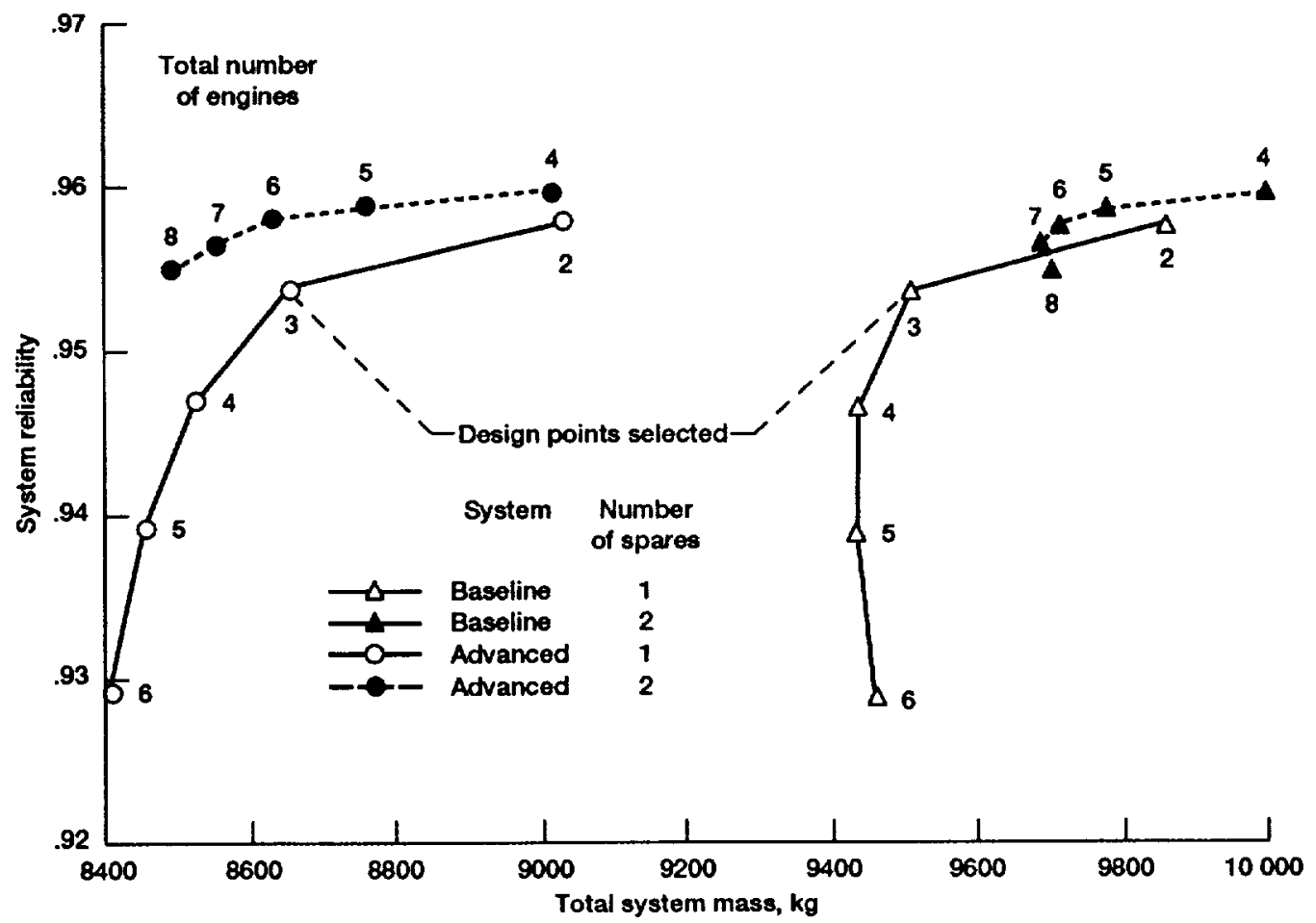

Figure 9.-100-kWe system reliability and mass tradeoff. 


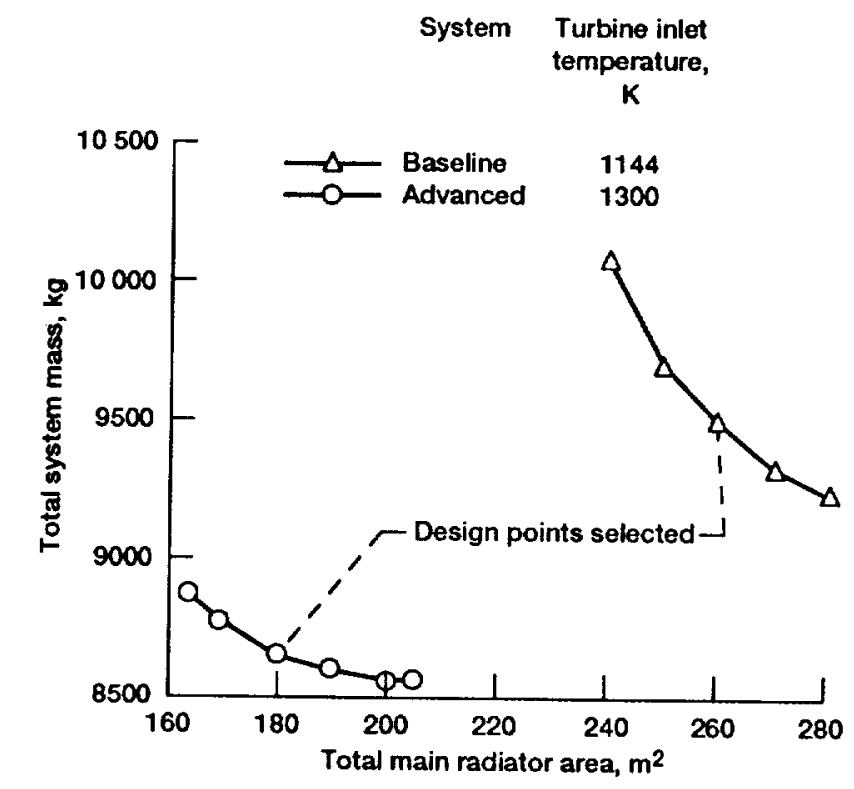

Figure 10. $-100-\mathrm{kWe}$ system mass and radiator tradeoff.

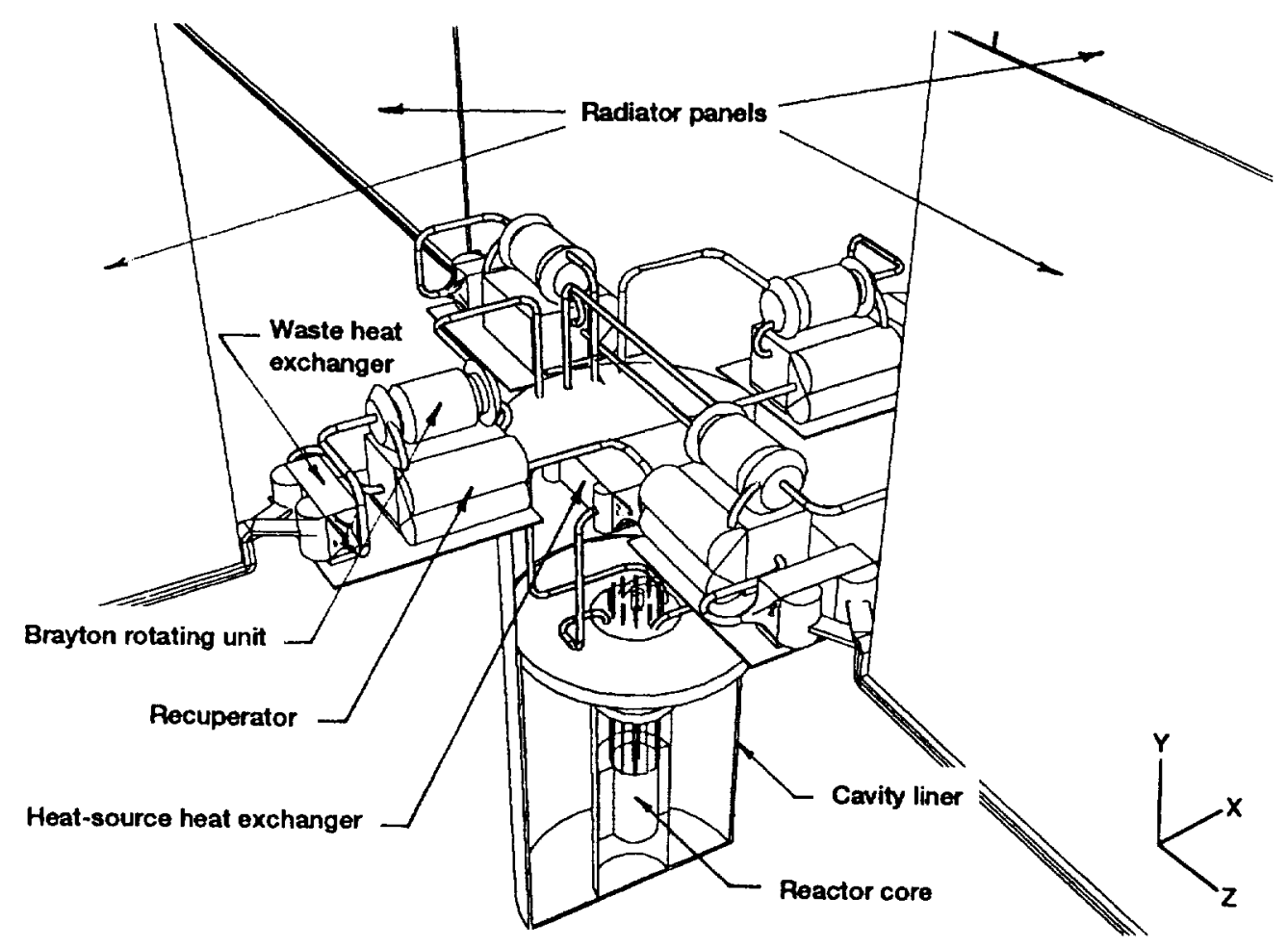

Figure 11.-550-kWe system design layout. 


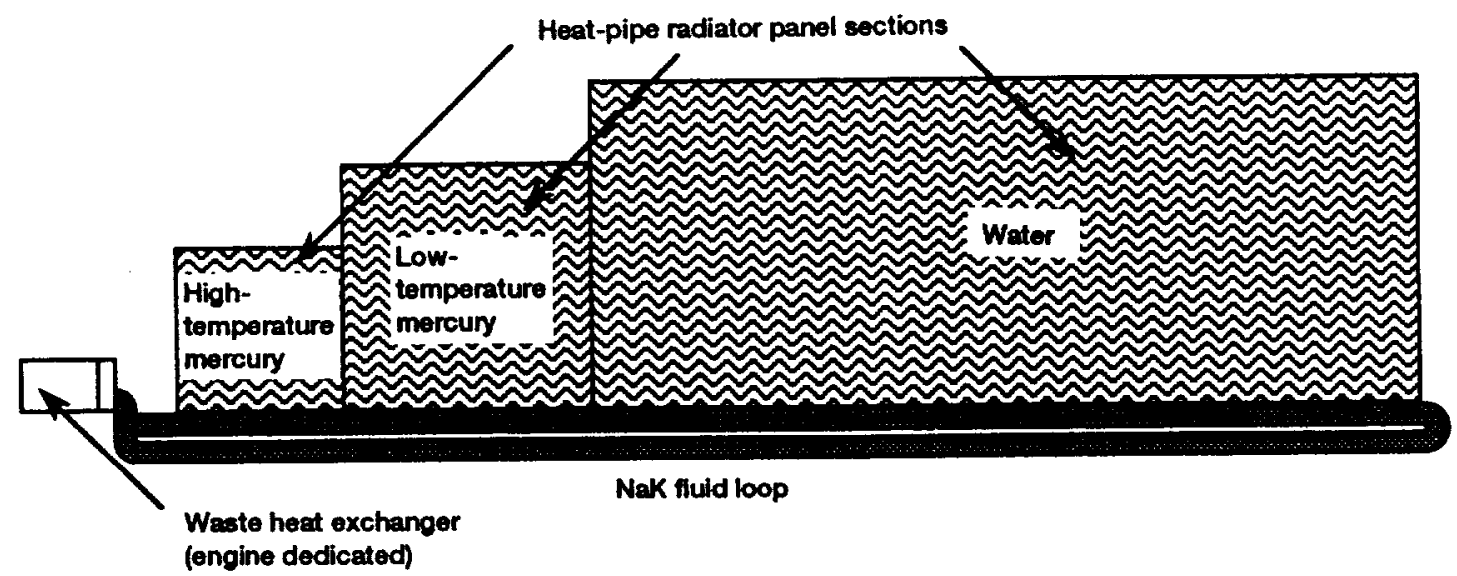

Figure 12. -550-kWe system radiator design (side view).

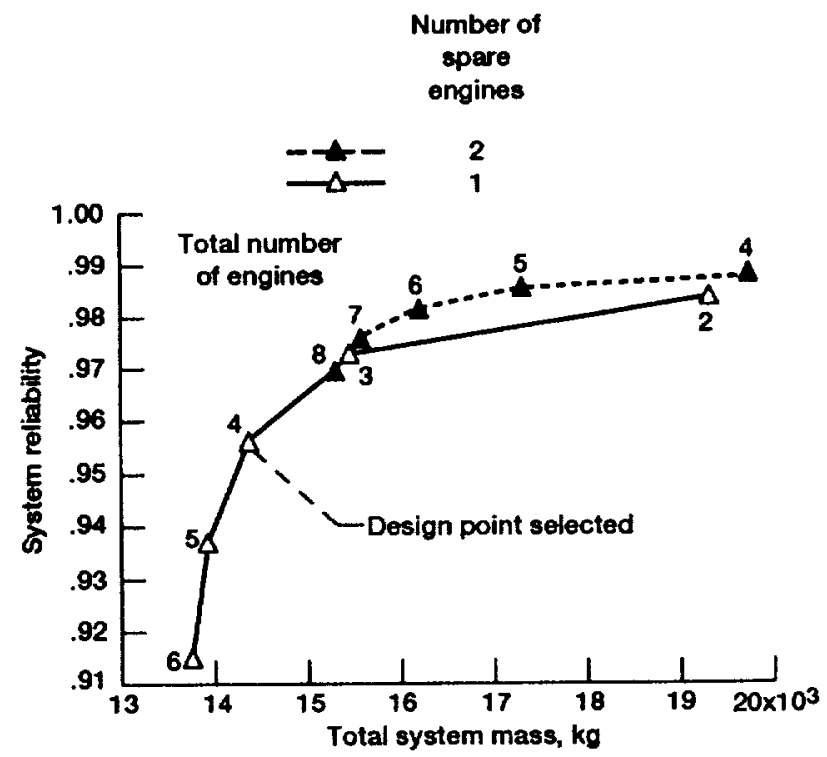

Figure 13. $-550-k$ We system reliability and mass tradeoff.

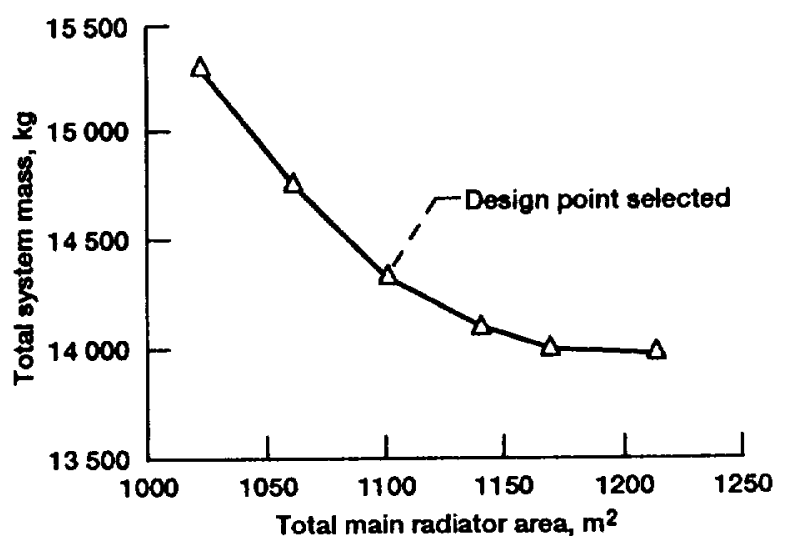

Figure 14.-550-kWe system mass and radiator area tradeoff. 

Public reporting burden for this collection of information is estimated to average 1 hour per response, inciuding the time for reviewing instructions, searching existing data sources, gathering and maintaining the data needed, and completing and reviewing the collection of information. Send comments regarding this burden estimate of any other aspect of this collection of information, including suggestions for reducing this burden, to Washington Headquarters Services, Directorate for information Operations and Reports, 1215 Jett
Davis Highway, Suite 1204 , Arlington, VA 22202-4302, and to the Oflice of Management and Budget, Paperwork Reduction Project (0704-018B), Washington. DC 20503

\begin{tabular}{|l|c|c|}
\hline 1. AGENCY USE ONLY (Leave blank) & $\begin{array}{c}\text { 2. REPORT DATE } \\
1992\end{array}$ & $\begin{array}{r}\text { 3. REPORT TYPE AND DATES COVERED } \\
\text { Technical Memorandum }\end{array}$
\end{tabular}

4. TITLE AND SUBTITLE

SP-100 Reactor With Brayton Conversion for Lunar Surface Applications

6. AUTHOR(S)

Lee S. Mason, Carlos D. Rodriguez, Barbara I. McKissock, James C. Hanlon, and Brian C. Mansfield

7. PeRforming organization name(S) AND AddRESS(ES)

National Aeronautics and Space Administration

Lewis Research Center

Cleveland, Ohio 44135-3191

9. SPONSORING/MONITORING AGENCY NAMES(S) AND ADDRESS(ES)

National Aeronautics and Space Administration

Washington, D.C. 20546-0001
5. FUNDING NUMBERS

$$
\text { WU-506-49-11 }
$$

8. PERFORMING ORGANIZATION REPORT NUMBER

E-6983

10. SPONSORING/MONITORING AGENCY REPORT NUMBER

NASA TM -105637

\section{SUPPLEMENTARY NOTES}

Prepared for the Ninth Symposium on Space Nuclear Power Systems, Albuquerque, New Mexico, January 12-16, 1992. Lee S. Mason,

Carlos D. Rodriquez, and Barbara 1. McKissock, NASA Lewis Rescarch Center. James C. Hanlon, Sverdrup Technology, Inc., Lewis

Rescarch Center Group, 2001 Aerospace Parkway, Brook Park, Ohio 44142; and Brian C. Mansfield, University of Dayton, Dayton, Ohio 44509. Responsible person, Lee S. Mason, (216) 433-7106.

12a. DISTRIBUTION/AVAILABILITY STATEMENT

12b. DISTRIBUTION CODE

Unclassified - Unlimited

Subject Category 20

13. ABSTRACT (Maximum 200 words)

This study examines the potential for integrating Brayton-cycle power conversion with the SP-100 reactor for lunar surface power system applications. Two designs were characterized and modeled. The first design integrates a $100-\mathrm{kWe}$ SP-100 Brayton power system with a lunar lander. This system is intended to meet early lunar mission power needs while minimizing on-site installation requirements. Man-rated radiation protection is provided by an integral multilayer, cylindrical lithium hydride/tungsten $(\mathrm{LiH} / \mathrm{W})$ shield encircling the reactor vessel. Design emphasis is on ease of deployment, safety, and reliability while utilizing relatively near-term technology. The second design combines Brayton conversion with the $\mathrm{SP}-100$ reactor in an erectable $550-\mathrm{kWe}$ powerplant concept intended to satisfy later-phase lunar base power requirements. This system capitalizes on experience gained from operating the initial $100-\mathrm{kWe}$ module and incorporates some technology improvements. For this system the reactor is emplaced in a lunar regolith excavation to provide man-rated shielding, and the Brayton engines and radiators are mounted on the lunar surface and extend radially from the central reactor. Design emphasis is on performance, safety, long life, and operational flexibility.

\section{SUBJECT TERMS}

Space power; Lunar power, Nuclear power; Brayton cycle; SP-100 reactor

17. SECURITY CLASSIFICATION OF REPORT Unclassified
18. SECURITY CLASSIFICATION OF THIS PAGE

Unclassified
19. SECURTY CLASSIFICATION OF ABSTRACT Unclassified 